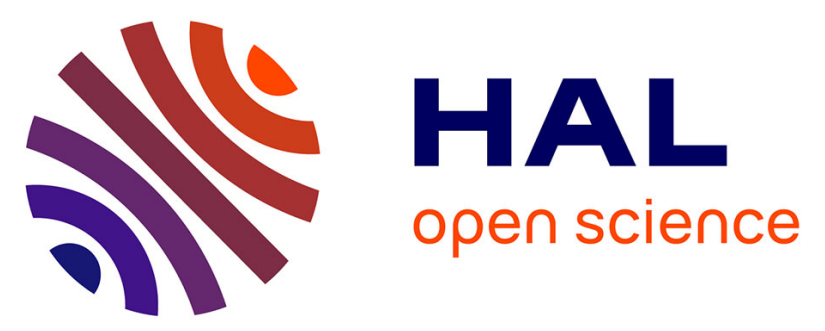

\title{
Lack of evidence for association of two functional SNPs of CHI3L1 gene (HC-gp39) with rheumatoid arthritis
}

Sanjeev K. Srivastava, Péter Antal, János Gál, Gábor Hullám, Ágnes F. Semsei, György Nagy, András Falus, Edit I. Buzás

\section{To cite this version:}

Sanjeev K. Srivastava, Péter Antal, János Gál, Gábor Hullám, Ágnes F. Semsei, et al.. Lack of evidence for association of two functional SNPs of CHI3L1 gene (HC-gp39) with rheumatoid arthritis. Rheumatology International, 2010, 31 (8), pp.1003-1007. 10.1007/s00296-010-1396-3 . hal-00615343

\section{HAL Id: hal-00615343 https://hal.science/hal-00615343}

Submitted on 19 Aug 2011

HAL is a multi-disciplinary open access archive for the deposit and dissemination of scientific research documents, whether they are published or not. The documents may come from teaching and research institutions in France or abroad, or from public or private research centers.
L'archive ouverte pluridisciplinaire $\mathbf{H A L}$, est destinée au dépôt et à la diffusion de documents scientifiques de niveau recherche, publiés ou non, émanant des établissements d'enseignement et de recherche français ou étrangers, des laboratoires publics ou privés. 
Sanjeev K Srivastava ${ }^{1}$, Péter Antal $^{2}$, János Gál ${ }^{3}$, Gábor Hullám ${ }^{2}$, Ágnes F Semsei ${ }^{1}$, György Nagy ${ }^{1,4}$, András Falus ${ }^{1,5}$ and Edit I Buzás ${ }^{1}$

\section{Lack of evidence for association of two functional SNPs of CHI3L1 gene (HC-gp39) with rheumatoid arthritis}

\footnotetext{
${ }^{1}$ Semmelweis University, Dept. Genetics, Cell- and Immunobiology, Nagyvárad tér 4. 1089, Budapest, Hungary

${ }^{2}$ Department of Measurement and Information Systems, Budapest University of Technology and Economics, Budapest, Pf. 91. 1521 Budapest, Hungary

${ }^{3}$ Department of Rheumatology, County Hospital Kecskemét, Nyíri út 38. Pf: 149.6000, Hungary

${ }^{4}$ Polyclinic of the Hospitaller Brothers of St. John of God in Budapest, 1022 Budapest, Zsigmond köz

7,Hungary,

${ }^{5}$ Research Group for Inflammation Biology and Immunogenomics, Hungarian Academy of Sciences, Nagyvárad tér 4. 1089 Budapest, Hungary
}

Corresponding author:

Edit I Buzas

Semmelweis University

Department of Genetics, Cell- and Immunobiology

Budapest, Nagyvarad ter 4. H-1089 Hungary

e-mail: edit.buzas@gmail.com 
Abstract

CHI3L1 gene encodes for a glycoprotein (HC-gp39 or YKL40) secreted by synovial fibroblasts, macrophages, neutrophil granulocytes and chondrocytes. Its expression is under the control of NF-kB. It is regarded as an acute phase protein, and its levels are significantly elevated in rheumatic diseases.

Furthermore, HC-gp39 has been shown to be recognized by autoreactive T cells in rheumatoid arthritis. In the present study we have examined two functional variants of the promoter region of CHI3L1 gene (CHI3L1-1 (rs4950928) and CHI3L1-2 (rs10399931) that have been reported earlier to be associated with schizophrenia and sarcoidosis. We used TaqMan allelic discrimination assays to study the genotypes of Hungarian patients with rheumatoid arthritis $(n=182)$ and of healthy controls $(n=194)$. No significant association of the investigated SNPs with the disease was found.

Here we report that CHI3L1 SNPs, shown to be involved in the predisposition of schizophrenia, are not associated with rheumatoid arthritis. 
Introduction

Rheumatoid arthritis (RA) is a common systemic inflammatory disease affecting approximately $1 \%$ of the adult population worldwide [1]. The disease is characterized by inflammation of synovial tissue,

progressive cartilage destruction and bone erosion of affected joints. [2]

Despite of significant gains in knowledge of the immunopathology of RA, the exact etiology of the disease remains uncertain [1]. The genetic basis for RA is rather complex with a poorly understood cause. Several studies suggest roles of HLA- DRB1 [3] and PTPN22 [4-6] in RA pathogenesis. Three further RA risk loci have been identified recently, including the STAT4 gene [7-9], loci in the 6q23 [10-11] and TRAF1/C5

[12-13]. As RA is a major cause of disability and is even correlated with increased mortality in severe cases [14]. Identification of genetic risk factors of RA may help to understand basic mechanisms of autoimmunity and may be helpful in the development of targeted diagnostics and therapeutics.

Chitinase-3-like1 (CHI3L1) is a glycoprotein also known as human cartilage glycoprotein-39 (HC gp-39) or YKL-40. It has also been suggested to be a growth factor for connective tissue cells as well as a migration-promoting factor for endothelial cells [15].

It is has been first described as a major secretory product of rheumatoid synovial fibroblasts by Nyirkos et al. [16]. Later it was demonstrated to be produced by articular chondrocytes and macrophages [17].

Its expression is under control of NF-kB [18] . CHI3L1 mRNA was shown to be expressed in diseased human osteoarthritic cartilage and osteophyte, while it was not detected in healthy adult cartilage [19]. Peptides derived from HC gp-39 can bind to RA- associated DR4 (DRB1*0401) molecules and are recognized by peripheral blood T cells from patients with RA [20]. Furthermore, elevated levels of CHI3L1 are reported to be associated with inflammatory disorders, such as RA [21-23].

Recently, functional variants of the promoter region CHI3L1 (including rs4950928) have been shown to be associated with susceptibility to schizophrenia [24]. Also, a CHI3L1 gene polymorphism (rs10399931) has been reported to contribute to inter-individual variations of the CHI3L1 levels in sarcoidosis [25].

Given the known elevated levels of CHI3L1 in various inflammatory diseases reported by numerous groups [21-23], in this study we made an attempt to identify a possible disease association of functional single nucleotide polymorphisms (SNPs) of CHI3L1 in a Hungarian cohort of patients with RA and healthy controls. 
Materials and methods

Subjects

We examined 182 patients suffering from RA (156 females, 26 males, mean age 61,98 $\pm 10,51$, range 3285), treated in the Department of Rheumatology, County Hospital Kecskemét, Hungary.

Control subjects (94 males and 100 females; aged 36.8 \pm 10.5 years) with no known history of inflammatory arthritis were randomly selected from healthy blood donors $(n=192)$ of the same ethnicity and from the same geographical region as the patients. All study subjects belonged to the Hungarian (Caucasian) population, and all RA patients had the typical symptoms and diagnosis of RA. All RA patients met the American College of Rheumatology criteria for rheumatoid arthritis [26].

During the entire investigation period the guidelines and regulations approved by the local Ethical Committee and the Helsinki Declaration in 1975 were followed; the patients gave their informed consent for use of their anonymized DNA samples for research purposes.

\section{Genotyping}

Genomic DNA was extracted from EDTA anticoagulated whole blood-derived buffy coats, after sedimentation at room temperature. A commercial kit QIAamp® DNA blood mini kit (QIAGEN Inc, Chatsworth, CA, USA) was used following the instructions of the manufacturer.

Biallelic SNP genotyping was performed with TaqMan allelic discrimination assays (Applied Biosystems) according to the recommendations of the manufacturer. PCR was performed using an ABI 7000 thermocycler, and fluorescent signals were analyzed using an ABI 7000 sequence detector single point measurement and SDS v2.3 software (Applied Biosystems).

The following assays were used for allelic discrimination in the study:

CHI3L1-1 (rs10399931) and CHI3L1-2 (rs4950928). PCR was performed with components including12,5 $\mu \mathrm{l}$ Mastermix, $9.2 \mu \mathrm{l}$ distilled water, $2 \mu \mathrm{DNA}(10 \mathrm{ng} / \mu \mathrm{l}), 1.3 \mu \mathrm{l}$ of primers and probes. The total reaction mixture was thus, $25 \mu \mathrm{l} /$ well. The following cycle was repeated 45 times: $50^{\circ} \mathrm{C}-2 \mathrm{~min}, 95^{\circ} \mathrm{C}-10 \mathrm{~min}$, $95^{\circ} \mathrm{C}-15 \mathrm{sec}, 60^{\circ} \mathrm{C}-1 \mathrm{~min}$. 
Clinical and laboratory parameters

Gender, age of onset of the disease, levels of C-reactive protein (CRP), seropositivities for rheumatoid factor (RF) and anti-CCP antibodies, and the current disease activity scores (DAS28) of the patients were documented for all patients with RA. Controls did not suffer from any known joint diseases.

\section{Statistical analysis}

Genotypes were determined for all samples, and each SNP was assessed for deviation from HardyWeinberg equilibrium. Both allelic and genotypic association tests and Cochran-Armitage tests were performed using an online HWE calculator (http://ihg2.helmholtz-muenchen.de/cgi-bin/hw/hwa1.pl) [27]. Associations with susceptibility to RA were tested by calculating odds ration (OR) and 95\% confidence interval (CI).

Results

We tested the possible association of two functional SNPs of the CHI3L1 gene with RA in a Hungarian cohort of patients by using allelic discrimination system. The baseline characteristics of the patients are summarized in Table 1.

Genotype frequencies were determined for both tested SNPs. Allele and genotype frequencies of the SNPs were calculated and are shown in Table 2. No deviation from the Hardy- Weinberg equilibrium (HWE) was observed either in RA patients or in controls. A comparison of allele and genotype frequencies of the polymorphism under study revealed no statistically significant differences between RA patients and healthy controls (Table 3).

After adjusting for age and gender using logistic regression, there was no significant association between the SNP-s and RA (we tested also their interaction) (data not shown).

Discussion 
RA is a systemic autoimmune disease with complex genetic background, and dissecting its genetic components may shed light on important mechanism underlying the development of autoimmunity in susceptible individuals.

Several studies examined the role of CHI3L1 and reported to be associated with inflammatory disorders, such as RA [21-23]. Recently, the promoter SNP of the CHI3L1 gene (rs4950928) was found to be associated with elevated serum CHI3L1 levels as well in asthma, bronchial hyperresponsiveness, and measures of pulmonary functions [29]. The same polymorphism was also demonstrated to be associated with schizophrenia [27].

The elevated levels and suggested role of CHI3L1 in the regulation of cytokine signaling as well as its protective role in inflammatory environments [28] were compelling to hypothesize that functional polymorphisms of the CHI3L1gene might be associated with RA.

Surprisingly, there were no significant differences in the distributions of alleles and genotypes between the RA patients and controls. Haplotype analysis of these two polymorphisms did not show differences between the two groups either.

We also carried out power analysis in order to refine our conclusions. Assuming a dominant model, the sample size in the study (377), and a significance level 0.05 , we investigated the power for the estimated allele frequency range $(22 \%-29.5 \%)$ and the estimated OR range $(<4)$. We found that the power diminished below $\mathrm{OR}=2$, thus, based on our data, we can not exclude associations with RA below this level.

Our present data argue that the reported elevated CHI3L1 levels in RA might be consequences rather than causative components of the inflammatory processes in RA. However, further SNPs of the CHI3L1 gene need to be tested in order to entirely rule out the association of the gene with RA susceptibility.

\section{Acknowledgements}

This work has been supported by grants OTKA 73247, OTKA77537, MRTN-CT-2005-019561, NKTH (National Research and Technology) TECH 08-A1/2-2008-0120, OTKA PD-76348. György Nagy and Peter Antal are J. Bolyai Research Fellows.

\section{Conflict of interest}


The authors declare that they have no conflict of interest. 


\section{References}

1. Lee DM, Weinblatt ME (2001) Rheumatoid arthritis. Lancet 358:903-11. doi. 10.1016/S01406736(01)06075-5

2 Lorentzen JC, Flornes L, Eklow C, Backdahl L, Ribbhammar U, Guo JP (2007) Association of arthritis with a gene complex encoding C-type lectin-like receptors. Arthritis Rheum 56: 2620-32. doi 10.1002/art.22813

3. Newton JL, Harney SM, Wordsworth BP, Brown MA (2004) A review of the MHC genetics of rheumatoid arthritis. Genes Immun 5: 151-7. doi:10.1038/sj.gene.6364045

4. Begovich AB, Carlton VE, Honigberg LA, Schrodi SJ, Chokkalingam AP, Alexander HC (2004) A missense single-nucleotide polymorphism in a gene encoding a protein tyrosine phosphatase (PTPN22) is associated with rheumatoid arthritis. Am J Hum

Genet 75:330-7. doi: 10.1086/422827

5. Orozco G, Sanchez E, Gonzalez-Gay MA, Lopez-Nevot MA, Torres B, Caliz RA (2005) Association of a functional single-nucleotide polymorphism of PTPN22, encoding lymphoid protein phosphatase, with rheumatoid arthritis and systemic lupus erythematosus. Arthritis Rheum 52:219-24. 10.1002/art.20771

6. Lee YH, Rho YH, Choi SJ, Ji JD, Song GG, Nath SK (2007) The PTPN22 C1858T functional polymorphism and autoimmune diseases — a meta-analysis. Rheumatology (Oxford) 46:49-56. doi:10.1093/rheumatology/kel170

7. Remmers EF, Plenge RM, Lee AT, Graham RR, Hom G, Behrens TW (2007) STAT4 and the risk of rheumatoid arthritis and systemic lupus erythematosus. N Engl J Med 357:977-86.doi:

\subsection{6/NEJMoa073003}

8. Lee HS, Remmers EF, Le JM, Kastner DL, Bae SC, Gregersen PK.(2007) Association of STAT4 with rheumatoid arthritis in the Korean population. Mol Med 13:455-60. doi: 10.2119/2007-00072 9. Orozco G, Alizadeh BZ, Delgado-Vega AM, Gonzalez-Gay MA, Balsa A, Pascual-Salcedo D (2008) Association of STAT4 gene with rheumatoid arthritis: a replication study in three European populations. Arthritis Rheum 58:1974-80. doi 10.1002/art.23549

10. Thomson W, Barton A, Ke X, Eyre S, Hinks A, Bowes J (2007) Rheumatoid arthritis association at 6q23. Nat Genet 39: 1431-3. doi:10.1038/ng.2007.32 
11. Plenge RM, Cotsapas C, Davies L, Price AL, de Bakker PI, Maller J (2007) Two independent alleles at $6 q 23$ associated with risk of rheumatoid arthritis. Nat Genet 39:1477-82. doi: 10.1038/ng.2007.27

12. Plenge RM, Seielstad M, Padyukov L, Lee AT, Remmers EF, Ding B (2007) TRAF1-C5 as a risk locus for rheumatoid arthritis — a genomewide study. N Engl J Med 357:1199-209. doi:

10.1056/NEJMoa073491

13. Kurreeman FA, Padyukov L, Marques RB, Schrodi SJ, Seddighzadeh M, Stoeken-Rijsbergen G. (2007) A candidate gene approach identifies the TRAF1/C5 region as a risk factor for rheumatoid arthritis. PLoS Med 4:e278. doi:10.1371/journal.pmed.0040278

14. Kroot E, Van Leeuwen MA, Van Rijswijk MH, Prevoo M, Van ’t Hof M,

Van de Putte LBA,Van Riel PLC. (2000) No increased mortality in patients with rheumatoid arthritis: up to 10 years of follow up from disease onset. Ann Rheum Dis 59:954-958. doi: 10.1136/ard.59.12.954

15 Yamada K, Hattori E, Iwayama Y, Toyota T, Ohnishi T, Iwata Y, Tsuchiya KJ, Sugihara G, Kikuchi M, Okazaki Y, Yoshikawa T. (2008) Failure to confirm genetic association of the CHI3L1 gene with schizophrenia in Japanese and Chinese populations. Am J Med Genet B Neuropsychiatr Genet. 508-514. 10.1002/ajmg.b.30847

16 Nyirkos P, Golds EE.(1990) Human synovial cells secrete a 39 kDa protein similar to a bovine mammary protein expressed during the non-lactating period. Biochem J 269: 265-8.

17 Hakala BE, White C, Recklies AD (1993) Human cartilage gp-39, a major secretory product of articular chondrocytes and synovial fluid cells, is a mammalian member of a chitinase protein family. J Biol Chem 268: $25803-10$.

18 Recklies AD, Ling H, White C, Bernier SM.(2005) Inflammatory cytokines induce production of CHI3L1 by articular chondrocytes. J Biol Chem 280: 41213-21. doi 10.1074/jbc.M510146200

19 Connor J, Dodds R, Emery J, Kirkpatrick R, Rosenberg M and Gowen M.(2000) Human cartilage glycoprotein 39 (HC gp-39) mRNA expression in adult and fetal chondrocytes, osteoblasts and osteocytes by in-situ hybridization.Osteoarthritis and Cartilage 8: 87-95 doi.10.1053/joca.1999.0276 20 Verheijden GF, Rijnders AW, Bos E, Coenen-de Roo CJJ, van Staveren CJ, Miltenburg AM (1997) Human cartilage glycoprotein-39 as a candidate autoantigen in rheumatoid arthritis. Arthritis Rheum 40: 1115-25. doi. 10.1002/1529-0131(199706) 
21 Vos K, Steenbakkers P, Miltenburg A, Bos E, Van den Heuve M, Van Hogezand R, De Vries R, Breedveld F, Boots A. (2000) Raised human cartilage glycoprotein-39 plasma levels in patients with rheumatoid arthritis and other inflammatory conditions. Ann Rheum Dis 59:544-548 doi:

10.1136/ard.59.7.544

22 Johansen JS, Jensen HS, Price PA (1993) A new biochemical marker for joint injury. Analysis of YKL40 in serum and synovial fluid. Br J Rheumatol 32:949-55.

23 Johansen JS, Hvolris J, Hansen M, Backer V, Lorenzen I, Price PA. (1996). Serum YKL-40 levels in healthy children and adults. Comparison with serum and synovial fluid levels of YKL-40 in patients with osteoarthritis or trauma of the knee joint. Br J Rheumatol 35: 553-559

24 Zhao X, Tang R, Gao B, Shi Y, Zhou J, Guo S, Zhang J, Wang Y, Tang W, Meng J, Li S, Wang H, Ma G, Lin C, Xiao Y, Feng G, Lin Z, Zhu S, Xing Y, Sang H, St Clair D, He L. (2007) Functional variants in the promoter region of Chitinase 3-like 1 (CHI3L1) and susceptibility to schizophrenia. Am J Hum Genet 80: 12-18. doi. $10.1086 / 510438$

25 Kruit A, Grutters J, Ruven H, Moorsel C, Van Den Bosch J. (2007) A CHI3L1 gene polymorphism is associated with serum levels of YKL-40, a novel sarcoidosis marker. Respiratory Medicine 101:1563-1571. doi. 10.1016/j.rmed.2006.12.006

26 Arnett FC, Edworthy SM, Bloch DA, McShane DJ, Fries JF, Cooper NS, Healey LA, Kaplan SR, Liang MH, Luthra HS (1988) The American Rheumatism Association 1987 revised criteria for the classification of rheumatoid arthritis. Arthritis Rheum 31:315-24

27 Wigginton JE, Cutler DJ, Abecasis GR. (2005). A note on exact tests of Hardy-Weinberg equilibrium. American Journal of Human Genetics 76: 887-893. doi. 10.1086/429864

28 Ling H, Recklies AD (2004) The chitinase 3-like protein human cartilage glycoprotein 39 inhibits cellular responses to the inflammatory cytokines interleukin-1 and tumour necrosis factor-alpha. Biochem J 380: 651-659. doi. 10.1042/BJ20040099

29 Ober C, Tan Z, Sun Y, Possick JD, Pan L, Nicolae R, Radford S, Parry RR, Heinzmann A, Deichmann KA, Lester LA, Gern JE, Lemanske RF Jr, Nicolae DL, Elias JA, Chupp GL (2008) Effect of variation in CHI3L1 on serum YKL-40 level, risk of asthma, and lung function. N Engl J Med. 358: 1682-1691. doi. 10.1056/NEJMoa0708801 
Table 1.

Cases in this study
$\mathrm{n}=182$$\quad \begin{aligned} & \text { Controls } \\ & \mathrm{n}=194\end{aligned}$

\begin{tabular}{|c|c|c|c|}
\hline \multicolumn{3}{|c|}{ Age of onset of the disease } & NA \\
\hline Sex*** & female & 156 & 100 \\
\hline & male & 26 & 94 \\
\hline $\log R F^{\#}$ & & $3.56(1.62)$ & ND \\
\hline $\log$ anti-CCP ${ }^{\&}$ & & $3.53(1.85)$ & ND \\
\hline DAS-28 & & $5.17(1.27)$ & ND \\
\hline $\mathrm{ESR}^{\# \#}$ & & $19.64(17.92)$ & ND \\
\hline
\end{tabular}

Table 2. Genotype and allele frequencies of CHI3L1polymorphisms in patients with RA and controls

\begin{tabular}{|c|c|c|c|c|c|c|c|c|}
\hline SNP & Allele & $\begin{array}{c}\text { Case } \\
\text { (frequency \%) }\end{array}$ & $\begin{array}{c}\text { Control } \\
\text { (frequency \%) }\end{array}$ & Genotype & $\begin{array}{c}\text { Case } \\
\text { (frequency \%) }\end{array}$ & $\begin{array}{c}\text { Control } \\
\text { (frequency } \\
\% \text { ) }\end{array}$ & $\begin{array}{c}\text { HWE } \\
\text { (p value } \\
\text { Case) }\end{array}$ & $\begin{array}{l}\text { HWE } \\
\text { (p value } \\
\text { control) }\end{array}$ \\
\hline CHI3L1-1 & $\mathrm{C}$ & $280(76.4)$ & 302 (77.8) & $\mathrm{CC}$ & $108(59.34)$ & $116(59.79)$ & $0,897^{\mathrm{x}}$ & $0.524^{x}$ \\
\hline rs4950928 & G & $84(23.1)$ & $86(22.2)$ & $\begin{array}{l}\mathrm{CG} \\
\mathrm{GG}\end{array}$ & $\begin{array}{c}64(35.16) \\
10(5.49)\end{array}$ & $\begin{array}{c}70(36.08) \\
8(4.12)\end{array}$ & $\begin{array}{l}0,898^{\#} \\
0,837^{\S}\end{array}$ & $\begin{array}{l}0.517^{\#} \\
0.677^{\S}\end{array}$ \\
\hline $\begin{array}{l}\text { CHI3L1-2 } \\
\text { rs10399931 }\end{array}$ & $\begin{array}{l}\mathrm{C} \\
\mathrm{T}\end{array}$ & $\begin{array}{l}259(72.4) \\
106(27.6)\end{array}$ & $\begin{array}{l}281(70.8) \\
107(29.2)\end{array}$ & $\begin{array}{l}\text { CC } \\
\text { CT } \\
\text { TT }\end{array}$ & $\begin{array}{c}93(51.09) \\
73(40.10) \\
17(9.34)\end{array}$ & $\begin{array}{c}100(51.54) \\
81(41.75) \\
13(6.70)\end{array}$ & $\begin{array}{l}0.627^{x} \\
0.628^{\#} \\
0.596^{\S}\end{array}$ & $\begin{array}{l}0.528^{x} \\
0.524^{\#} \\
0.593^{\S}\end{array}$ \\
\hline
\end{tabular}


Table 3. Tests for association with RA (C.I:95\% confidence interval)

\begin{tabular}{llllll} 
Risk allele & $\begin{array}{l}\text { Allele freq. } \\
\text { difference }\end{array}$ & Heterozygous & Homozygous & Allele positivity & $\begin{array}{l}\text { Armitage's } \\
\text { trend test }\end{array}$ \\
\hline & & & & & \\
CHI3L1-1 & OR=1.053 & $\mathrm{OR}=0.982$ & $\mathrm{OR}=1.343$ & $\mathrm{OR}=1.019$ & $\mathrm{OR}=1.085$ \\
Allele 2 & $\mathrm{C} . \mathrm{I}=[0.748-1.483]$ & $\mathrm{C} . \mathrm{I}=[0.640-1.507]$ & $\mathrm{C} . \mathrm{I}=[0.511-3.527]$ & $\mathrm{C} . \mathrm{I}=[0.675-1.539]$ & $\mathrm{P}=0.76296$ \\
& $\mathrm{p}=0.76510$ & $\mathrm{p}=0.93382$ & $\mathrm{p}=0.54884$ & $\mathrm{P}=0.92870$ & \\
CHI3L1-1 & $\mathrm{OR}=0.949$ & $\mathrm{OR}=0.731$ & $\mathrm{OR}=0.745$ & $\mathrm{OR}=0.740$ & $\mathrm{OR}=0.925$ \\
Allele 1 & $\mathrm{C} . \mathrm{I}=[0.674-1.336]$ & $\mathrm{C} . \mathrm{I}=[0.272-1.968]$ & $\mathrm{C} . \mathrm{I}=[0.284-1.957]$ & $\mathrm{C} . \mathrm{I}=[0.285-1.918]$ & $\mathrm{P}=0.76296$ \\
& $\mathrm{P}=0.76510$ & $\mathrm{P}=0.53447$ & $\mathrm{P}=0.54884$ & $\mathrm{P}=0.53382$ & \\
& & & & & \\
CHI3L1-2 & $\mathrm{OR}=1.085$ & $\mathrm{OR}=0.969$ & $\mathrm{OR}=1.406$ & $\mathrm{OR}=1.030$ & \\
Allele 2 & $\mathrm{C} . \mathrm{I}=[0.790-1.489]$ & $\mathrm{C} . \mathrm{I}=[0.634-1.481]$ & $\mathrm{C} . \mathrm{I}=[0.648-3.053$ & $\mathrm{C} . \mathrm{I}=[0.687-1.542]$ & $\mathrm{OR}=1.122$ \\
& $\mathrm{p}=0.61385$ & $\mathrm{p}=0.88452$ & $\mathrm{p}=0.38743$ & $\mathrm{p}=0.88780$ & $\mathrm{P}=0.61300$ \\
CHI3L1-2 & OR=0.922 & $\mathrm{OR}=0.689$ & $\mathrm{OR}=0.711$ & $\mathrm{OR}=0.701$ & \\
Allele 1 & $\mathrm{C} . \mathrm{I}=[0.672-1.265]$ & $\mathrm{C} . \mathrm{I}=[0.313-1.516$ & $\mathrm{C} . \mathrm{I}=[0.328-1.544]$ & $\mathrm{C} . \mathrm{I}=[0.331-1.488]$ & $\mathrm{OR}=0.895$ \\
& $\mathrm{p}=0.61385$ & $\mathrm{p}=0.35308$ & $\mathrm{p}=0.38743$ & $\mathrm{p}=0.35331$ & $\mathrm{P}=0.61300$
\end{tabular}

Allele frequency difference:- [1]<->[2] \&[2]<->[1], Homozygous :- [11+]<->[22] \&[22]<->[11]

Heterozygous :- $[11]<->[12] \&[22]<->[12]$, Allele positivity :- $[11]<->[12+22]$ and $[11+12]<->[22]$

C.I.: confidence interval, OR : odds ratio 